\title{
Pemberdayaan Ekonomi Masyarakat Melalui Budidaya Ikan Lele dengan Teknologi Sistem Bioflok di Era Pandemi Covid-19
}

\author{
Muhammad Jamil ${ }^{1}$, Teuku Muhammad Faisal ${ }^{2}$ \\ 1,2,Universitas Samudra \\ email : milcareca@gmail.com ${ }^{1}$, teukumuhammadfaisal@gmail.com²
}

\begin{abstract}
Community service is one of the implementations of the Tridharma of Higher Education that must be carried out to develop knowledge and technology as well as innovation to the community, especially the community who are partners in service activities. The problem that needs a solution for the community of fish cultivating groups is "Tiara Jaya" which is one of the productive fishery business groups in Bayeun Village, Birem Bayeun District, East Aceh Regency which is a partner in this community service activity with biofloc technology innovation. Weak mastery of catfish cultivation technology at partner locations is the main basis for the community service team from Samudra University to assist the Pokdakan in mastering the technology so that later cultivators can apply it in catfish cultivation activities with biofloc system technology. The use of biofloc technology is considered to provide significant benefits for farmers because this technology can save on the use of feed. After being introduced to the use, benefits, and methods of using biofloc technology in implementing catfish farming, Tiara Jaya partners and farmers in Bayeun Village are expected to be interested in this technology so that it can be applied to catfish cultivation with a biofloc system in the future.
\end{abstract}

Keywords: catfish cultivation, biofloc system, covid-19.

\begin{abstract}
Abstrak
Pengabdian kepada masyarakat (PKM) merupakan salah satu pelaksanaan Tridharma Perguruan Tinggi yang harus dilakukan dalam rangka untuk mengembangkan pengetahuan dan teknologi serta inovasi kepada masyarakat terutama masyarakat yang menjadi mitra dalam kegiatan pengabdian. Permasalahan yang perlu mendapat solusi terhadap masyarakat kelompok pembudidaya ikan (POKDAKAN) yaitu "Tiara Jaya" yang merupakan salah satu kelompok usaha perikanan produktif yang ada di Desa Bayeun, Kecamatan Birem Bayeun Kabupaten Aceh Timur yang menjadi mitra dalam kegiatan pengabdian kepada masyarakat (PKM) ini dengan inovasi teknologi bioflok. Lemahnya penguasaan teknologi budidaya lele di lokasi mitra menjadi dasar utama tim pengabdi kepada masyarakat dari Universitas Samudra untuk membantu Pokdakan tersebut dalam menguasai teknologi tersebut sehingga nantinya pembudidaya dapat menerapkannya dalam kegiatan budidaya ikan lele dengan teknologi sistem bioflok. Penggunaan teknologi bioflok ini dirasa memberi manfaat yang signifikan bagi pembudidaya karena teknologi ini bisa menghemat penggunaan pakan. Setelah diperkenalkan penggunaan, manfaat dan cara penggunaan teknologi bioflok dalam menerapkan budidaya ikan lele kepada mitra Tiara Jaya dan pembudidaya yang ada Desa Bayeun ini diharapkan tertarik dengan teknologi tersebut agar dapat diaplikasikan pada usaha budidaya ikan lele dengan sistem bioflok di masa mendatang.
\end{abstract}

Kata Kunci: budidaya lele, sistem bioflok, covid-19

\begin{tabular}{|c|c|c|}
\hline Artikel diterir & direvisi : 25 Agustus 2021 & disetujui : 1 September 2021 \\
\hline (c) (7) (?) & $\begin{array}{l}\text { Ciptaan disebarluaskan di bawah Lisensi } \\
\text { BerbagiSerupa 4.0 Internasional. }\end{array}$ & Creative Commons Atribusi- \\
\hline
\end{tabular}




\section{Pendahuluan}

Pelaku usaha yang bergerak di bidang budidaya lele di desa Bayeun, kecamatan Bireum Bayeun, kabupaten Aceh Timur memang sudah ada, tapi masih sedikit dan masih bersifat konvensional dalam aspek budidayanya, padahal prospeknya sangat bagus untuk dijadikan sebagai sebuah peluang usaha bagi masyarakat. Ikan lele merupakan jenis ikan darat yang paling banyak dibudidayakan di Indonesia. Budidaya lele dapat dilakukan dalam skala kecil, menengah maupun sampai besar. Lokasi pembudidayaannya juga dapat dilakukan di dataran rendah maupun tinggi (Tim Karya Tani Mandiri, 2018).

Untuk dapat melaksanakan kegiatan budidaya tersebut tentu harus didukung oleh sumberdaya yang tersedia sehingga masyarakat dapat berpikir untuk membuka usaha tersebut. Tim pengabdian kepada masyarakat (PKM) dari Universitas Samudra bekerjasama dengan mitra, yaitu Kelompok Pembudidaya Ikan (POKDAKAN) "Tiara Jaya" yang ada di desa Bayeun, kecamatan Birem Bayeun, kabupaten Aceh Timur dalam rangka untuk budidaya lele dengan teknologi sistem bioflok. Kemampuan dari hasil penyampaian materi dan praktek yang didapatkan oleh kelompok mitra Pokdakan dari Tim Pengabdi dapat dijadikan sebuah peluang usaha bagi mitra dalam membuka usaha tersebut, baik dalam hal produksi maupun manajemen. Disamping itu pelaku usaha Pokdakan juga akan mendapatkan informasi-informasi terkait akses pemasaran dari hasil panen nantinya dengan demikian rantai pasok (supply chain) dapat berjalan dengan baik sehingga usaha dapat berjalan lancar dan mampu meningkatkan perekonomian masyarakat pedesaan.

Proses transfer materi dan praktek teknologi sistem bioflok dari tim pengabdi Universitas Samudra kepada Pokdakan Tiara Jaya dan masyarakat setempat untuk dapat menangani berbagai permasalahan termasuk masalah produksi dan manajemen usaha. Prospek usaha budidaya lele sangat baik untuk dijalankan karena pasarnya terbuka lebar, terutama di perkotaan sehingga kemungkinan mengalami kerugian dalam berusaha sangat kecil, apabila mampu mendeteksi masalah harga di pasar. Namun karena situasi sekarang yang lagi pandemi Corona Virus Disease (Covid-19) maka denyut nadi perekonomian masyarakat akan terganggu. Corona Virus Disease (Covid-19) ini menyebabkan penyakit mulai dari gejala ringan sampai berat (Direktorat Jenderal Pencegahan dan Pengendalian Penyakit Kementerian Kesehatan RI, 2020).

Pelaku usaha (Pokdakan) "Tiara Jaya" sebagai mitra dapat memanfaatkan informasi teknologi budidaya sistem bioflok yang didapatkan dari tim pengabdi untuk dapat dijadikan sebagai sebuah peluang usaha bagi masyarakat. Permasalahan pemasaran akan dijajaki dengan membangun kerjasama dengan mitra yang bergerak di bidang pemasaran hasil produksi di perkotaan atau warung-warung (restoran) yang menjajakan menu lele sebagai salah satu menu makanannya. Namun dengan adanya situasi sekarang yang lagi pandemi Covid-19 ini maka denyut nadi perekonomian masyarakat terganggu.

Permasalahan Mitra Kelompok Pembudidaya Ikan (POKDAKAN) "Tiara Jaya" berupa produksi: pertama, masih terbatasnya modal yang dimiliki pembudidaya untuk memulai usaha budidaya lele, sarana dan prasarana yang terbatas, pengetahuan, teknologi dan inovasi serta tingkat kreatifitas dalam memanfaatkan secara efesien lahan untuk pembudidayaan lele.

Kedua, kebiasaan atau pola pikir yang ada pada masyarakat sangat sulit untuk diubah, serta kurang tanggap terhadap berbagai perubahan terutama dalam alih teknologi dan inovasi. Ketiga, pendidikan formal masyarakat sebagian besar masih sangat rendah sehingga berpengaruh terhadap pengetahuan yang dimiliki seseorang. Semakin tinggi tingkat pendidikan semakin tanggap terhadap perubahan yang terjadi, begitu juga sebaliknya, sehingga pembudidaya dapat menangkap dengan 
cepat berbagai informasi yang penting bagi pengembangan ekonomi masyarakat, termasuk budidaya lele dengan teknologi bioflok.

Keempat, mencoba membangun komunikasi dan kerjasama dengan masyarakat agar dapat menumbuhkan motivasi yang dimiliki peternak untuk memulai usaha budidaya ikan lele, sehingga mengajak masyarakat umum untuk ikut bekerjasama dalam tim pengabdian masyarakat dalam rangka mempelajari dan alih teknologi dan inovasi dalam bidang usaha ternak ikan lele sehingga nantinya menemukan jati diri yang lebih mantap sehingga bersedia menjadi peternak ikan lele dengan sistem bioflok dalam rangka peningkatan produksi ikan lele yang berpengaruh kepada pendapatan dan kesejahteraan keluarga.

Kelima masih rendahnya motivasi yang dimiliki pembudidaya untuk memulai usaha budidaya lele, sehingga tim PKM Universitas Samudra memberikan motivasi dengan memberikan pelatihan dan sosialisasi kepada Mitra Tiara Jaya untuk dapat menjalankan usaha tersebut sehingga nantinya menjadi lebih mandiri dalam bertindak dan mengambil tindakan ke arah peningkatan hasil produksi lele.

Solusi terkait produksi berupa: pertama menggugah mitra Tiara Jaya sebagai salah satu Pokdakan di desa untuk merubah sikap dan tindakan ke arah yang lebih positif terutama dalam hal pembudidayaan lele sehingga usaha ini nantinya akan dapat menopang ekonomi rumah tangga melalui respon terhadap alih teknologi dan inovasi.

Kedua mendorong Pokdakan Tiara Jaya untuk meningkatkan pendidikan melalui jalur non formal sehingga pendidikan yang rendah dapat teratasi sehingga berpengaruh kepada pengetahuan yang dimiliki seseorang. Semakin tinggi tingkat pendidikan semakin respon terhadap perubahan, begitu juga sebaliknya. Pendidikan yang tinggi dan didukung oleh pengalaman akan lebih lebih dalam mengambil tindakan terutama informasi tentang budidaya ikan lele dengan teknologi bioflok.
Beberapa permasalahan dan solusi yang berkaitan dengan manajemen: pertama jaringan pemasaran belum dapat dikuasai dengan baik dan tepat sehingga perlu diupayakan penjajakan jaringan pemasaran yang lebih terjamin untuk pemasaran lele guna memberikan manfaat dan peningkatan pendapatan kepada pembudidaya ikan di Gampong Bayeun, kecamatan Birem Bayeun, kabupaten Aceh Timur. Perlu membangun kerjasama dengan berbagai pihak dalam upaya mengembangkan kelembagaan kelompok pembudidaya ikan sehingga kelompok ini menjadi kelompok yang mandiri dan berkelanjutan.

Kedua membangun jaringan pemasaran walaupun saat ini belum diperoleh secara pasti, namun dengan berkat kerja keras dan kerja cerdas jaringan pemasaran akan dapat dikuasai dengan cepat apabila memiliki kemauan yang tinggi, untuk pemasaran lele guna memberikan manfaat dan peningkatan pendapatan kepada pembudidaya ikan khususnya Pokdakan Tiara Jaya yang ada di desa Bayeun, kecamatan Birem Bayeun, kabupaten Aceh Timur.

Permasalahan yang bersifat spesifik, kongkrit, serta benar-benar merupakan prioritas Mitra yaitu: pertama peserta kegiatan (mitra) Pokdakan Tiara Jaya belum begitu mengetahui dengan benar dalam hal aplikasi teknologi bioflok untuk budidaya lele. Kedua kemampuan ekonomi masyarakat yang ada di desa Bayeun, kecamatan Birem Bayeun, kabupaten Aceh Timur berasal dari kalangan yang tidak mampu secara ekonomi sehingga diperlukan program pengabdian kepada masyarakat. Ketiga alih teknologi budidaya lele dengan sistem bioflok harus disosialisasikan kepada masyarakat dengan benar karena masyarakat sangat membutuhakan informasi tersebut.

\section{Metode Pelaksanaan}

Metode pelaksanaan yang dilakukan dalam program pengabdian kepada masyarakat dapat ditempuh dengan menggu- 
nakan metode pendidikan dan pelatihan serta metode demontrasi plot (demplot). Menurut Ekasari (2009) dalam Kurniawan dan Asriani (2016), teknologi bioflok merupakan alternatif teknologi yang saat ini sedang dikembangkan dalam akuakultur yang bertujuan untuk memperbaiki kualilas air dan meningkatkan efisiensi pemanfaatan nutrient. Teknologi ini didasarkan pada konversi nitrogen anorganik terutama ammonia oleh bakteri heterotrof menjadi biomassa mikroba yang kemudian dapat dikonsumsi oleh organisme budidaya.

Hal ini didukung juga oleh Adharani dkk. (2016) menambahkan bahwa teknologi bioflok merupakan salah satu alternatif untuk mengatasi masalah kualitas air lingkungan budidaya yang diadaptasi dari teknik pengelolaan limbah secara konvensional. Disamping itu kini, budidaya lele umumnya dikelola secara intensif. Budidaya lelepun sebagai rantai awal bisnis lele mempunyai peluang yang cukup besar untuk mendukung pemerintah dalam program membuka lapangan kerja dan meningkatkan pendapatan masyarakat (Direktorat Produksi dan Usaha Budidaya, Kementerian Perikanan dan Kelautan Republik Indonesia, 2017).

Budidaya ikan lele dengan sistem bioflok merupakan teknologi baru dalam pembudayaan ikan lele, namun sistem tersebut belum begitu popular di masyarakat, hal ini seperti dikemukakan oleh Setiawan dkk. (2016), "teknologi bioflokulasi merupakan salah satu teknologi yang saat ini sedang dikembangkan dalam akuakultur yang bertujuan untuk memperbaiki kualilas air dan meningkatkan efisiensi pemanfaatan nutrisi.

\section{Hasil dan Pembahasan}

Pelaksanaan kegiatan pengabdian kepada masyarakat yang ada di desa Bayeun, kecamatan Birem Bayeun, kabupaten Aceh Timur khususnya Pokdakan Tiara Jaya dapat dilakukan dengan pendekatan sebagai berikut:

Pertama, tahap awal pengenalan teknologi budidaya ikan lele dengan sistem bioflok di tengah suasana pandemi virus corona virus disease 2019 (Covid-19) kepada mitra yang terlibat dalam kegiatan pengabdian masyarakat.

Kedua, menjelaskan tahapan pelaksanaan teknologi budidaya lele dengan sistem bioflok di tengah suasana pandemi virus Corona Virus Disease 2019 (Covid19) kepada mitra yang terlibat dalam kegiatan pengabdian secara lebih rinci agar mitra dapat mengerti dan mudah untuk diaplikasi nantinya.

Ketiga, kepada mitra dijelaskan akan tahapan yang harus dilalui kalau teknologi budidaya ini diterapkan dan hasilnya nanti akan dibawa kemana sehingga produk yang dihasilkan memberikan nilai ekonomi kepada mitra.

Keempat, menginventarisir permasalahan mitra di saat penyampaian materi dan pelatihan secara praktek serta dilanjutkan dengan aplikasi teknologi ke dalam bentuk demplot (demontrasi plot).

Kelima, mencari solusi bersama antara tim PKM dengan mitra Pokdakan dalam memecahkan berbagai persoalan selama pelaksanaan kegiatan pengabdian berlangsung.

Keenam, merancang strategi ke depan setelah kegiatan pengabadian ini berlangsung agar mitra dapat melanjutkan usaha budidaya lele dengan sistem bioflok untuk dipasarkan sesuai pasar sasaran.

Ketujuh, menyangkut dengan aspek sosial, budaya, religi dan lainnya harus dapat dikelola dengan baik setiap persoalan yang muncul sehingga dapat dicari jalan keluar yang lebih bermakna.

Seluruh tahapan yang akan dilalui dalam kegiatan PKM ini baik pada saat diberikan materi materi menyangkut budidaya lele dengan sistem bioflok maupun saat praktek langsung berupa pelatihan di 
lapangan. Materi tersebut disampaikan kepada mitra Pokdakan Tiara Jaya dan beberapa masyarakat desa Bayeun yang hadir.

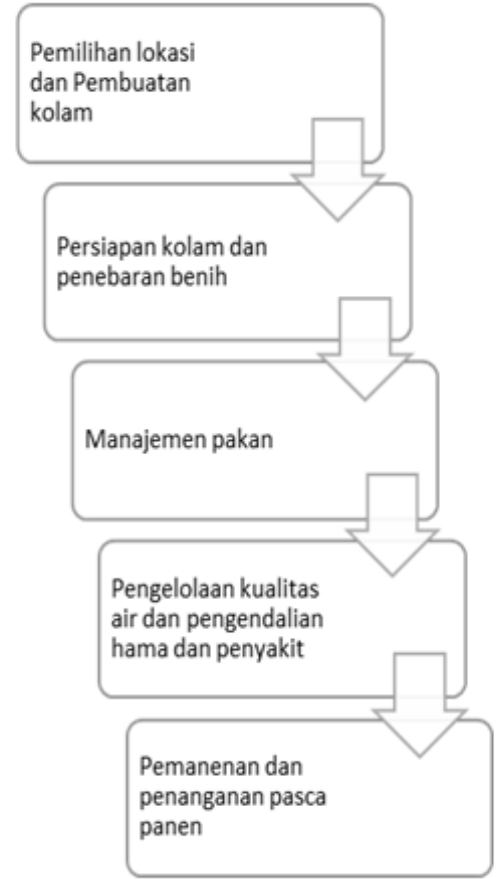

Gambar 1. Tahapan Pelaksanaan

Masing-masing pokok bahasan dilaksanakan dengan mengacu kepada rencana kegiatan yang disesuaikan alokasi waktu dan kegiatan seperti gambar 1 di atas.

\section{Kegiatan survei ke lokasi pengabdian}

Kedatangan tim Pengabdian Kepada Masyarakat (PKM) Universitas Samudra (UNSAM) ke lokasi mitra disambut langsung oleh Ketua Kelompok Pembudidaya Ikan (POKDAKAN) "Tiara Jaya", desa Bayeun, kecamatan Bayeun, kabupaten Aceh Timur yang selanjutnya dilakukan diskusi dengan ketua kelompok untuk menentukan tempat yang akan dibangun kolamnya, serta hal-hal lain yang dianggap perlu, seperti ketersediaan sumber air untuk mengisi kolam ikan nantinya. Hasil audiensi dengan ketua kelompok akan menjadi bahan pertimbangan bagi tim pengabdian untuk menentukan langkah berkutnya. Ketua Pokdakan "Tiara Jaya" Mahyudanil menyambut dengan antusias terhadap rencana pembangunan kolam bioflok lele di tempat mitra, hal ini juga mendapat respon dari anggota kelompok lainnya seperti gambar 2. di bawah ini.

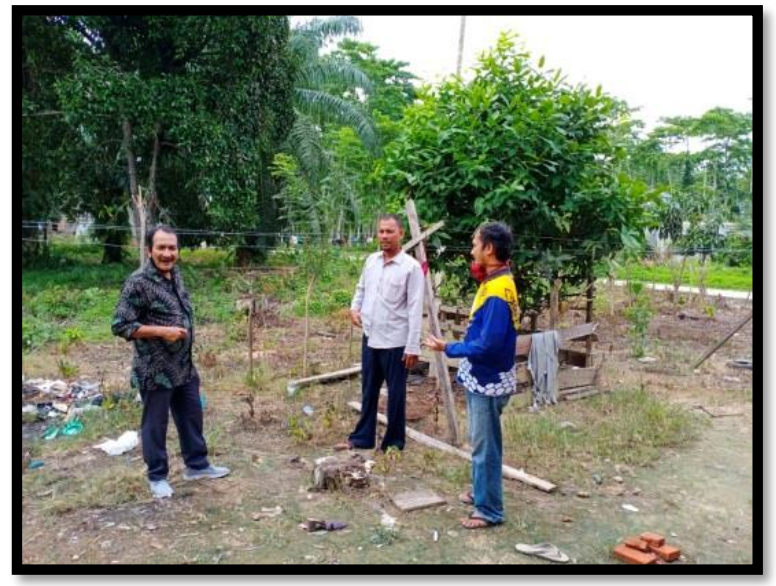

Gambar 2. Survey lokasi

Masyarakat berharap kolam bioflok yang akan dibangun dapat berjalan dengan baik dan mereka siap berpartisipasi dalam pembangunan kolam tersebut. Tim pengabdian UNSAM, menjelaskan tentang hal-hal yang berhubungan dengan syaratsyarat pembangunan kolam lele khususnya kolam bioflok. Ini merupakan kunjungan ke 1 dalam kegiatan pengabdian kepada masyarakat di desa Bayeun, kecamatan Birem Bayeun, kabupaten Aceh Timur.

\section{Kunjungan ke-2 Pokdakan "Tiara Jaya"}

Kegiatan ini dilakukan dalam rangka sosialisasi pelaksanaan PKM pada Pelatihan Budidaya lele dengan sistem bioflok di desa Bayeun, kecamatan Birem Bayeun, kabupaten Aceh Timur. Teknik budidaya lele sistem bioflok merupakan teknologi baru dalam budidaya ikan, termasuk untuk budidaya lele. Tahapan-tahapan yang harus dilakukan dalam budidaya ikan lele dengan sistem bioflok dipaparkan oleh ketua pelaksana pengabdian Bapak Ir. Muhammad Jamil, M.MA. dan dibantu oleh anggota tim pengabdian Teuku Muhammad Faisal, S.Kel., M.Si. yang merupakan dosen pada Program Studi Akuakultur, Fakultas Pertanian UNSAM. Pada pertemuan kali ini dihadiri oleh ketua 
Pokdakan dan peserta lainnya. Dalam rangka memudahkan aplikasi teknologi, tim pengabdian menyediakan brosur/ leaflet untuk diberikan kepada peserta pengabdian yang hadir. Dalam pertemuan kali ini juga membahas tentang jadwal pertemuann berikutnya. Kegiatan ini dlakukan pada tanggal 7 September 2020 seperti gambar 3 di bawah.

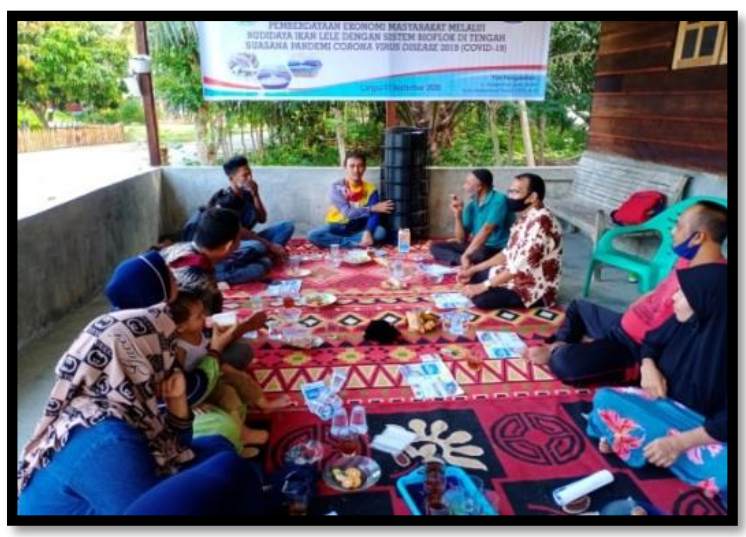

Gambar 3. Penyampaian materi

\section{Kunjungan ke-3 Kepada Kelompok Pembudidaya Ikan "Tiara Jaya"}

Kegiatan ini dilakukan sebagai tindak lanjut hasil sosialisasi yang telah dilakukan pada tanggal 7 September 2020. Pada kesempatan ini tim PKM Unsam melakukan kegiatan berupa pengenalan peralatan yang digunakan dalam pembuatan kolam ikan lele dan dijelaskan juga cara pemasangan kolam ikan lele, selanjutnya pengenalan bahan-bahan yang diperlukan untuk memudahkan dalam pemasangan kolam ikan lele dengan diameter kolam 3 meter. Sebelum kolam dipasang, terlebih dahulu di setting tempat rencana penempatan kolam dan dipasang secara bersama-sama dengan peserta pengabdian.

Setelah kolam dipasang maka dilakukan pengisian air ke dalam kolam, dan dibiarkan selama 24 jam, serta dikeringkan kembali sebelum benih lele di tebar. Setelah kolam dipasang, mesin pompa atau aerator di pasang agar ketersediaan oksigen dapat berjalan dengan baik. Air dibiarkan selama 2 hari agar ancaman racun pada terpal dapat dihilangkan. Setelah kolam selesai maka tim PKM mema- sukkan probiotik ke dalam kolam, dan dibiarkan selama seminggu atau sepeluh hari baru dimasukkan benih ikan lele seperti gambar 4 di bawah.

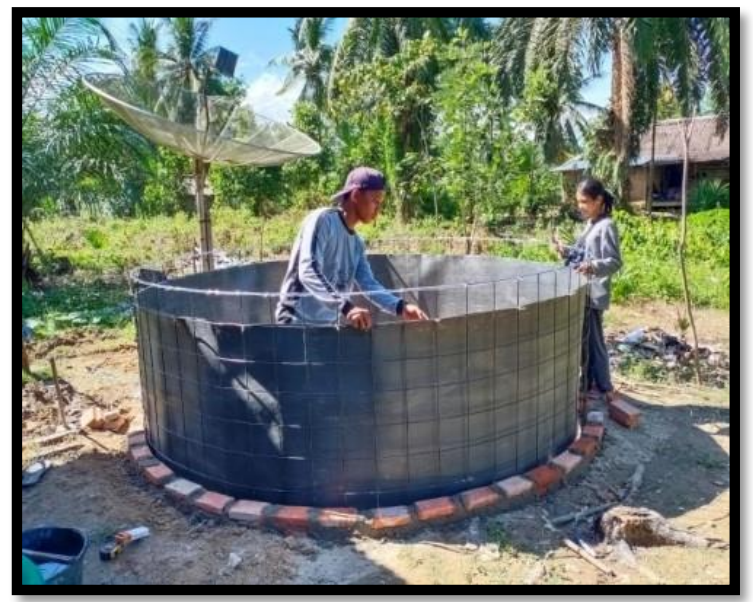

Gambar 4. Pembuatan kolam bioflok

\section{Kunjungan ke-4 Kepada Kelompok Pembudidaya Ikan "Tiara Jaya"}

Setelah tim PKM Unsam melaksanakan tahap pemasangan kolam ikan dengan diameter 3 meter, maka langkah selanjutnya yaitu melakukan penebaran benih ikan lele ke dalam kolam sebanyak 3000 ekor yang sudah berkuran $5 \mathrm{~cm}$. Kemudian ikan ditebar pada saat pagi atau sore hari, agar benih ikan tidak terganggu kesehatannya. Setelah itu pakan diberikan dari jenis yang masih pemula, kemudian sesuai dengan perubahan umur ikan maka pakanpun dicari yang cocok dengan umur ikan tersebut. Pakan diberikan sesuai dengan persentase tubuh bobot ikan.

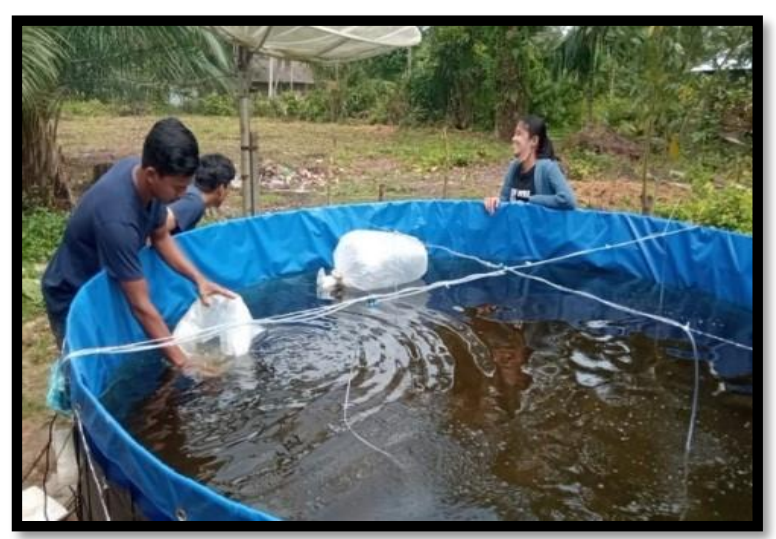

Gambar 5. Penebaran lele pada kolam bioflok 
Setiap sepuluh hari sekali ditambah probiotik ke dalam kolam, agar flok dapat tersedia dengan sempurna. Peserta PKM dengan semangat yang tinggi mengikuti acara penebaran benih dimaksud. Acara ini dilaksanakan tanggal 21 September 2020 seperti gambar 5 di atas.

\section{Kunjungan ke-5 Mendampingi Tim Monitoring Evaluasi (Monev) PKM Universitas Samudra}

Kegiatan terakhir yang dilakukan oleh tim PKM UNSAM adalah mendampingi tim monev. Berdasarkan hasil monitoring tim monev internal UNSAM terhadap kegiatan pengabdian kepada masyarakat Pokdakan Tiara Jaya, Kegiatan ini dilaksanakan pada tanggal 24 Oktober 2020 seperti gambar 6 di bawah.

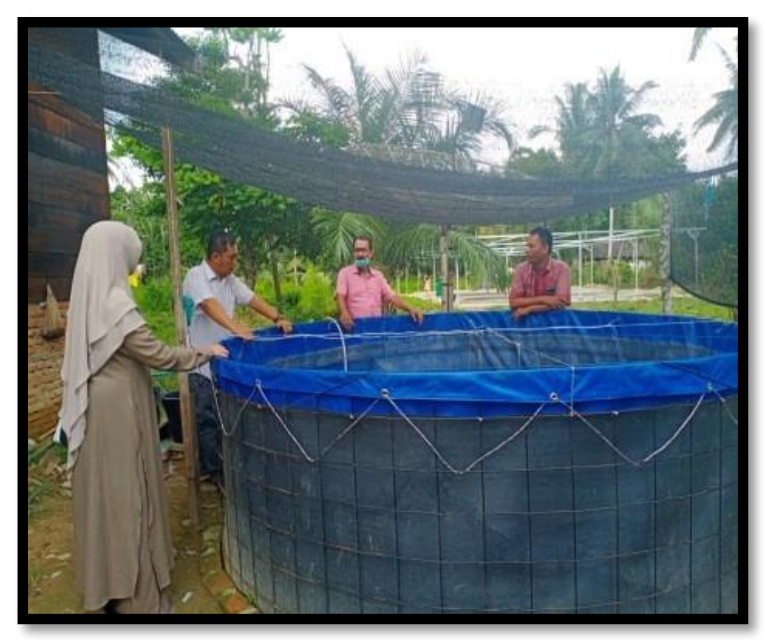

Gambar 6. Monev internal

\section{Simpulan}

\section{Penutup}

Pertama, kelompok pembudidaya ikan (POKDAKAN) "Tiara Jaya" telah memahami teknik budidaya lele dengan teknologi sistem bioflok, dengan menggunakan kolam terpal berdiameter 3 meter dengan tinggi 1,2 meter.

Kedua, kelompok Tiara Jaya sudah mampu melakukan budidaya lele sistem bioflok sendiri. Ketiga, kelompok Tiara Jaya dapat menjadikan usaha budidaya lele dengan teknologi sistem bioflok sebagai penambah pendapatan keluarga dan dapat dijadikan sebagai usaha alternatif di masa pandemi Covid-19.

\section{Saran}

Hendaknya instansi terkait dapat memberikan pendampingan dalam rangka pengembangan usaha kelompok, untuk saat ini dan dimasa mendatang. Dibutuhkannya bantuan peralatan yang lebih layak bagi usaha kelompok.

\section{Ucapan Terima Kasih}

Penulis mengucapkan terima kasih kepada Universitas Samudra atas pendanaan kegiatan ini melalui Hibah DIPA Tahun 2020 dan kelompok pembudidaya ikan (POKDAKAN) "Tiara Jaya" dan masyarakat desa Bayeun, kecamatan Bireum Bayeun, kabupaten Aceh Timur telah mendukung penuh dalam pelaksanaan program kegiatan pengabdian kepada masyarakat ini.

\section{Daftar Pustaka}

Adharani, N., Soewardi, K., Syakti, A. D., \& Hariyadi, S. (2016). "Manajemen kualitas air dengan teknologi bioflok: Studi kasus pemeliharan ikan lele (Clarias Sp.)". Jurnal Ilmu Pertanian Indonesia, 21(1), 35-40.

Direktorat Jenderal Pencegahan dan Pengendalian Penyakit Kementerian Kesehatan Republik Indonesia. (2020). Pedoman Kesiapsiagaan Menghadapi Coronavirus Disease (Covid-19). Direktorat Jenderal Pencegahan dan Pengendalian Penyakit Kementerian Kesehatan Republik Indonesia. Jakarta.

Direktorat Produksi dan Usaha Budidaya,

Kementerian Perikanan dan Kelautan Republik Indonesia. (2017). Buku Saku Budidaya Ikan Lele Sistem Bioflok. Direktorat Produksi dan Usaha Budidaya Kementerian Perikanan dan Kelautan Republik Indonesia. Jakarta.

Kurniawan, A., \& Asriani, E. (2016). "Aplikasi Kolam Bundar dan Bioflok pada Pembesaran Ikan Lele di 
Kelompok Remaja Masjid

Paritpadang, Sungailiat, Bangka".

Jurnal Pengabdian Kepada

Masyarakat Universitas Bangka

Belitung, 3(2).

LPPM dan PM. (2018). Panduan

Pelaksanaan Pengabdian Kepada

Masyarakat Tahun 2020. Universitas

Samudra Langsa. Langsa.

Rusherlistyani. (2017). Budidaya Lele dengan Sistem Kolam Bioflok. LPPM Universitas Veteran. Yogyakarta.

Setiawan, A., Ariqoh, R., Tivani, P., Pipih, L., \& Pudjiastuti, I. (2016).

"Bioflokulasi Sistem Teknologi Budidaya Lele Tebar Padat Tinggi Dengan Kapasitas 1M3/750 Ekor Dengan Flock Forming Bacteria". Jurnal Inovasi Teknik Kimia, 1(1).

Tim Karya Tani Mandiri. (2018). Rahasia Sukses Budidaya Ikan Lele. Nuansa Aulia. Bandung. 